положительных и отрицательных эмоций как переживание, но и важное условие формирования личности, нравственного развития [1].

Воспитателю необходимо изучая систему межличностных взаимоотношения детей дошкольного возраста в коллективе, помогать каждому дошкольнику занять благоприятную для его развития позицию среди сверстников. Именно взрослый может помочь ребёнку лучше узнать своих ровесников и увидеть в них такую же личность, как и он сам.

Основные условия формирования доброжелательных взаимоотношений у детей дошкольного возраста, которые необходимо организовать это: создать эмоциональноположительный климат в группе; моделировать педагогические ситуации, которые позволят детям проявлять доброжелательные отношения как к ровесникам, так и к окружающим людям.

Таким образом, формирование доброжелательных взаимоотношений у детей дошкольного возраста является довольно таки сложным процессом, при котором воспитание развития доброжелательного отношения, в основном, происходит через игры, через правильно построенное взаимодействие с ровесниками и воспитателем, различные формы общения.

$$
* * *
$$

1. Бабаева Т.Н. Формирование доброжелательного отношения детей старшего дошкольного возраста к сверстникам в процессе общения. -2001.

2. Галигузова Л.Н. Становление потребности детей в общении со взрослыми и сверстниками. - М., 2011.

3. Дубина Л. Развитие у детей коммуникативных способностей // Дошкольное воспитание. - 2009. №10. - C. 26-36.

4. Павленко Т. Почему они конфликтуют? / Т. Павленко, А. Рузская // Дошкольное воспитание. 2011. - №1. - С. 72-78.

\title{
Касарова В.Г., Ежовкина О.А. \\ Использование речевых конструкций для выражения мнения в контексте развития речи иностранных учащихся на занятиях по русскому языку (из опыта работы)
}

doi: $10.18411 / \mathrm{j}-06-2021-174$

\author{
МАДИ \\ (Россия, Москва)
}

\section{Аннотация}

В статье рассматриваются лексические единицы и конструкции, которые можно изучать в иностранной аудитории на уроках по речевой практике, приводятся многочисленные примеры по теме, посвященной выражению собственного мнения. Занятия по развитию речи очень важны для иностранных учащихся, преподавателю следует уделять им большое внимание. Используя опыт своей работы, авторы статьи рассказывают, каким образом возможно проведение уроков, посвященных речевой практике, какие задания можно давать иностранным учащимся, какие речевые конструкции желательно использовать. Иностранные учащиеся, изучающие русский язык, показывают неплохие результаты на подобных занятиях.

Ключевые слова: иностранные учащиеся, русский язык как иностранный, речевая практика, речевые конструкции, выражение собственного мнения, примеры, занятия по развитию речи, задания, использование лексических конструкций.

\section{Abstract}

The article examines lexical units and constructions that can be studied in a foreign audience in speech practice lessons, provides numerous examples on a topic dedicated to 
expressing one's own opinion. Speech development classes are very important for foreign students, the teacher should pay great attention to them. Using the experience of their work, the authors of the article tell how it is possible to conduct lessons on speech practice, what tasks can be given to foreign students, what speech structures it is desirable to use. Foreign students studying Russian show good results in such classes.

Keywords: foreign students, Russian as a foreign language, speech practice, speech constructions, expression of one's own opinion, examples, speech development classes, assignments, use of lexical constructions.

На занятиях по русскому языку в иностранной аудитории очень важно уделять большое внимание развитию речи учащихся. Преподавателю необходимо подбирать или создавать соответствующие тексты, упражнения, задания, презентации, чтобы содействовать расширению лексического запаса иностранных учащихся. Работа преподавателя русского языка на занятиях по развитию речевой деятельности учащихся способствует интенсификации учебного процесса. [1]

Одним из заданий на речевую практику в иностранной аудитории, на наш взгляд, должно быть с использованием фраз на выражение своего мнения. Преподавателю необходимо заранее продумать занятия по данной тематике. Иностранные учащиеся должны знать, какие фразы можно использовать, чтобы говорить о своем собственном мнении. Это очень важный аспект в речевой деятельности, поскольку всем людям нравится говорить, что они думают на ту или иную тему. Выражение собственных чувств и эмоций - необходимая составляющая в жизни каждого человека. [2]

В начале занятия нужно предложить иностранным учащимся использовать словосочетание «выражать - выразить мнение» в следующем контексте: «говорить сказать, что человек об этом думает». После этого необходимо научить учащихся обычной фразе, которую можно часто использовать и которая вряд ли вызовет у них какие-либо трудности: «Я думаю, что...» Также преподавателю следует дать несколько примеров с использованием этой фразы, например, «Я думаю, что русский язык очень трудный. А как вы думаете?» или «Я думаю, что изучать русский язык очень интересно», после чего предложить учащимся составить подобные фразы самостоятельно.

Преподавателю также необходимо ввести на занятии следующие фразы, подчеркнув, что по-русски также можно сказать: «на мой взгляд», «по моему мнению», «по-моему», сопроводив их примерами: «На мой взгляд, русский язык очень трудный», «С моей точки зрения, русский язык очень трудный», «По моему мнению, русский язык трудный, но очень красивый», «По-моему, русский язык не очень трудный.» При этом необходимо обратить внимание иностранных учащихся на ударение в словах и словосочетаниях «по-моему» и «по моему мнению», поскольку они похожи в письменном виде, но различаются при произношении. Также можно рассказать, что мы можем использовать более разговорную конструкцию, синонимичную предыдущим, «как по мне», например, «Как по мне, русский язык совсем не трудный» или «Как по мне, говорить по-русски не очень трудно.» Чтобы разнообразить речь учащихся, можно также ввести следующую конструкцию: «честно говоря», сопроводив ее примерами, «Честно говоря, я не хотела изучать русский язык, но потом узнала, что можно учиться в университете России. И сейчас, на мой взгляд, русский язык не очень трудный.» Выучив данные слова и словосочетания, иностранные учащиеся могут рассказать, что они думают о той или иной вещи, о том или ином человеке, событии и т.д., т.е. выразить собственное мнение. После введения данных лексических единиц, преподаватель может предложить обучающимся какую-либо тему, чтобы они могли на практике использовать предъявляемые конструкции, а также привести свои примеры. 
Преподавателю необходимо предъявить достаточное количество примеров с представленными конструкциями, включающими слова и словосочетания, чтобы учащиеся поняли, как можно их использовать в речевых оборотах. Таким образом, можно определенное время на занятии по русскому языку отвести на речевую практику иностранных учащихся. Мы рекомендуем преподавателям во время подобных занятий не только проговаривать данные им примеры, повторять их несколько раз, писать на доске, но также предлагать учащимся фиксировать их в тетради, приводить свои примеры на данную тему. Различные примеры с данными конструкциями, повторяемые преподавателем и учащимися на занятии, несомненно, помогут их запоминанию. [3]

После отработки примеров с предлагаемыми выше конструкциями, преподаватель может ввести новые лексические единицы, относящиеся к заданной теме. Например, написать слова, выражающие уверенность и неуверенность говорящего на ту или иную тему, которые можно использовать в речевой практике. При этом, необходимо объяснить учащимся, что такое уверенность или неуверенность, используя известную им лексику. Например, можно сказать так: «Уверенность или неуверенность - это ситуация, когда люди точно знают или не знают, что это так, когда они уверены или не уверены в чем-либо.» Для объяснения данной категории преподавателю лучше разделить доску на две части и объяснять по очереди с помощью примеров все возможные нюансы. Например, можно написать и затем озвучить следующие лексические единицы, фразы, показывающие уверенность: «Я уверен(а) (в том), что...» После этого необходимо дать несколько примеров, например: «Я уверен в том, что этот учебник будет интересным и полезным для иностранных учащихся.» Или «Я уверена, что вам понравится этот учебник».

Также нужно показать учащимся, что существуют синонимичные фразы, например: «Я не сомневаюсь (в том), что», «Я не сомневаюсь, что вы сможете хорошо говорить по-русски после окончания подготовительного факультета». Также можно дать учащимся следующие фразы: «Я убежден (в том), что» и «Я убеждена (в том), что» и развить эту тему с помощью примеров, например: «Я убеждена, что изучение русского языка может быть интересным». В то же время существует возможность использования таких слов, как «без сомнения», «несомненно». Можно объяснить эти слова уже приведенными ранее примерами, например: «Я уверена», «Я не сомневаюсь», «Я точно это знаю», «Без сомнения вы сможете выучить русский язык» или «Несомненно, вы сможете хорошо говорить по-русски».

После ряда примеров, приведенных сначала преподавателем, а затем учащими, можно озвучить с необходимыми комментариями следующие лексические единицы, показывающие неуверенность человека. Мы предлагаем использовать следующие фразы: «Я не уверен(а) (в том), что» и привести такие примеры: «Я не уверена, что завтра мы пойдем в парк.», «Я сомневаюсь (в том), что завтра будет хорошая погода.», «Возможно, мы не поедем в театр на следующей неделе.», «Вероятно, мы не будем отдыхать в субботу.», «Может быть, тебе нужно будет много заниматься в этом месяце.», «Мне кажется, что завтра будет холодно.», «Кажется, эту тему мы еще не изучали.», «Наверное, вы сейчас напишете это задание.»

Объясняя тему, посвященную выражению своего мнения, эмоций, чувств, преподавателю необходимо комментировать каждый свой пример, а также предлагать учащимся составить большое количество их собственных примеров. При этом важно подчеркнуть, что примеры эти могут быть на совершенно разные темы. Таким образом, давая иностранным учащимся свободу в выражении собственных эмоций и чувств на разные темы, преподаватель способствует развитию их речевой деятельности. [4]

Исходя из собственного опыта работы в иностранной аудитории, мы можем с уверенностью сказать, что подобные уроки по речевой практике воспринимаются учащимися очень позитивно и приводят к прекрасным результатам. Лексические 
единицы запоминаются намного легче, чем чтение, даже с объяснениями, грамматического правила в учебнике. [5]

Подводя итоги урока (части урока), преподаватель может предложить учащимся в качестве домашнего задания написать небольшой рассказ на какую-либо тему с обязательным использованием выученных ими конструкций, которые были предъявлены преподавателем. На следующем уроке этот рассказ каждый учащийся, например, может прочитать вслух для последующего обсуждения в группе.

Таким образом, преподаватель на уроке русского языка в иностранной аудитории может способствовать оптимизации и интенсификации учебного процесса и поднять его на качественно новый уровень, при этом не забывая решать повседневные вопросы и проблемы.

Правильная и продуманная организация процесса обучения является залогом эффективной работы преподавателя и учащихся. Занятия русского языка не должны быть перегружены новыми лексическими и грамматическими единицами. Преподаватель не должен забыть, что новые лексические единицы необходимо предъявлять на основе уже изученной грамматики. Новая грамматика должна даваться на основе уже знакомой учащимся лексики.

$$
* * *
$$

1. Касарова В.Г., Ежовкина О.А. Пути предупреждения речевых ошибок иностранных учащихся / Международное образование и сотрудничество. Сборник научных трудов. - М.: МАДИ, 2016. C. $36-42$.

2. Касарова В.Г., Ежовкина О.А. Работа над тавтологическими речевыми ошибками на уроках русского языка как иностранного // Сборник материалов V Международной научно-практической конференции «Профессионально направленное обучение русскому языку иностранных граждан. М.: МАДИ, 2017. - С .211-214.

3. Касарова В.Г. Речевые ошибки иностранных студентов и их причины // В сборнике «Гуманитарные науки». - М.: МАДИ, 2003. № 21.- С. 24-28.

4. Л.С. Кременецкая Проектирование содержания обучения иностранных граждан из стран СНГ на довузовском этапе в техническом вузе. Автореферат дис. ... кандидата педагогических наук / Московский государственный агроинженерный университет им. В.П. Горячкина. - М., 2013.

5. Л.С. Кременецкая Проектирование содержания обучения иностранных граждан из стран СНГ на довузовском этапе в техническом вузе. Диссертация ... кандидата педагогических наук: 13.00 .08 / Московский государственный агроинженерный университет им. В.П. Горячкина. - М., 2013.

\title{
Касарова В.Г., Кременецкая Л.С. \\ К вопросу об изучении собирательных числительных на уроках русского языка как иностранного (из опыта работы)
}

\author{
МАДИ \\ (Россия, Москва)
}

doi: 10.18411/lj-06-2021-175

\section{Аннотация}

В статье авторы рассматривают одну из самых сложных тем для иностранных учащихся - собирательные числительные. Авторы статьи считают, что данной теме надо уделать достаточное внимание, чтобы предупредить ошибки в речи иностранных учащихся. В статье даны примеры таких числительных, приведены способы их объяснения иностранным учащимся. Для изучения такой сложной темы необходимо большое количество примеров, в статье подобные примеры разбираются достаточно подробно, показывается их использование в речевых ситуациях.

Ключевые слова: иностранные учащиеся, собирательные числительные, примеры, русский язык как иностранный, оптимизировать работу, использование числительных, речевые ситуации. 